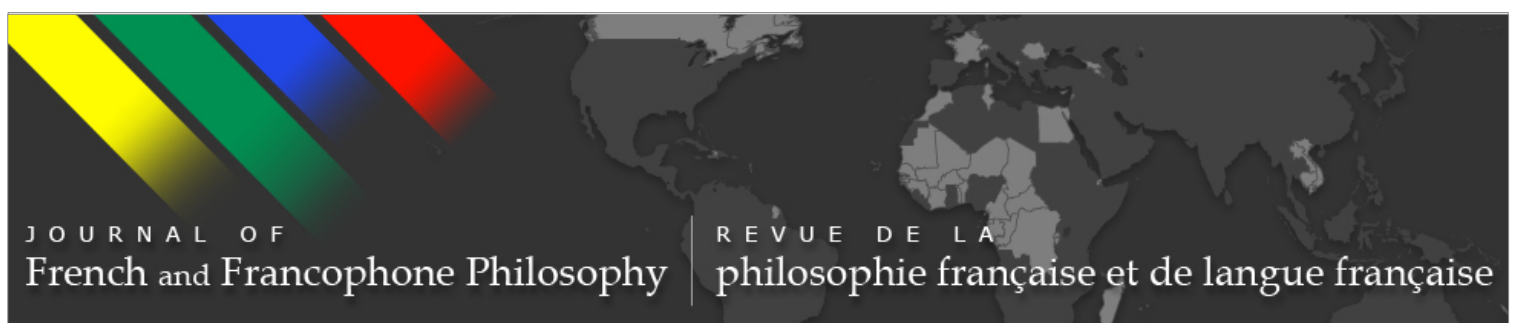

\title{
Deleuze and Epicurean Philosophy
}

\section{Atomic Speed and Swerve Speed}

Michael James Bennett

Journal of French and Francophone Philosophy - Revue de la philosophie française et de langue française, Vol XXI, No 2 (2013) pp 131-157

\author{
Vol XXI, No 2 (2013) \\ ISSN 1936-6280 (print) \\ ISSN 2155-1162 (online) \\ DOI 10.5195/jffp.2013.599 \\ www.jffp.org
}

\section{(oc) BY-NG-ND}

This work is licensed under a Creative Commons Attribution-Noncommercial-No Derivative Works 3.0 United States License.

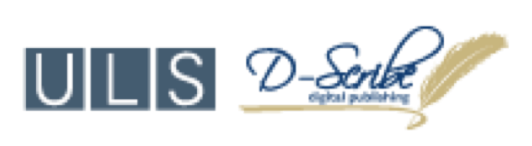

This journal is operated by the University Library System of the University of Pittsburgh as part of its D-Scribe Digital Publishing Program, and is co-sponsored by the University of Pittsburgh Press 



\title{
Deleuze and Epicurean Philosophy Atomic Speed and Swerve Speed
}

\author{
Michael James Bennett \\ McMaster University
}

Although Gilles Deleuze's appropriation of ancient Stoic ontology has been much scrutinized, both by Deleuzians and by Hellenists, ${ }^{1}$ his reading of Epicureanism has not received as much attention. ${ }^{2}$ This is a shame, since Deleuze's explicit reading of Epicurus in texts like "Lucretius and the Simulacrum" (1961) and Difference and Repetition (1968) sheds light on his conception of problematic ideas in a way that has not yet been fully perceived. Moreover, understanding Deleuze's reading of Epicurus clarifies the etiology of some of the more perplexing figures of his philosophy. In What is Philosophy? (1991), when Deleuze and Guattari formalize an image of thought, a meta-philosophical conception of what philosophy is or what it should be, they argue that philosophy strives to emulate the infinite speed of what they call "chaos" by means of creating concepts and installing a plane of immanence. Deleuze and Guattari's otherwise puzzling discussion of speed in What is Philosophy?, and particularly the "infinite speed" to which they assign such importance, should be understood as derived, at least in part, from a reading of Epicurus. It is also for the most part consistent with Deleuze's reading of Epicurean physics in 'Lucretius and the Simulacrum', with one or two exceptions. This paper explicates three of Deleuze's readings of Epicurus over the course of his career: first in Difference and Repetition, then in "Lucretius and the Simulacrum", and finally in What is Philosophy? Perceiving the continuities and discontinuities among these readings makes it possible to see that an appropriation of Epicurean physics is more central to Deleuze's philosophy than is often appreciated.

\section{The Epicurean Speed of Atoms}

Deleuze recognizes Epicurean atomism as an attempt to formalize a conception of problematic ideas, a precursor to his own attempt to do so in Difference and Repetition, because Epicurus explicitly conceived of ideas as multiplicities - in this case, "multiplicities of atoms, atoms being the objective elements of thought." ${ }^{3}$ Epicurus, that is, identifies thoughts or

Journal of French and Francophone Philosophy | Revue de la philosophie française et de langue française Vol XXI, No 2 (2013) | www.jffp.org | DOI 10.5195/jffp.2013.599 
ideas with compounds of atoms. Deleuze's reference to "sensible compounds" ${ }^{4}$ indicates that he is relying on Epicurus' theory of eidôla ("images", simulacra in Lucretius). And so Deleuze's interpretive claim cannot be fully understood without an analysis of Epicurean eidôla that Deleuze assumes but does not provide.

Epicurus contends that there is a kind of continuity between perception and conception. Having established that atoms are the principles of all things, Epicurus' Letter to Herodotus ${ }^{5}$ describes the ceaseless character of atomic movement. Atoms are always moving. ${ }^{6}$ Furthermore, they must all move at the same, constant speed, since the condition of atomic movement (the void) can't vary the speed of atoms by offering any differential resistance whatsoever. ${ }^{7}$ Epicurus also claims that any attempt to describe the edges or boundaries of compounds, far from being able to fall back on mathematical limit-entities, must account for the "outlines" of compounds, which are not zero-dimensional but atomic, just "much finer than the objects of which they are the outlines." 8 The constituent atoms of these outlines, like all atoms, must be constantly moving and must therefore have a certain speed. Epicurus describes the outlines as tupoi ("types", sometimes translatable as "stamps" or "impressions") having the same skhêma (shape or form) as the original compounds. A couple of lines later, Epicurus calls such homoschematic types "eidôla." 9 The conventional way of conceiving of eidôla is as films of very fine atoms that maintain for a relatively long time the schematic outline of whatever compound they were the edge of. Epicurus appears to be thinking thus: while in bodily compounds atoms bang into one another and are prevented from attaining the greatest speed they are capable of, at the edges of bodies the jumble of resisting atoms suddenly gives way and the component atoms of the eidôla attain their maximal natural speed; "since their movement through the void occurs with no conflict from [atoms which] could resist them, it can cover any comprehensively graspable distance in an inconceivably [short] time."10 Thus the persevering flow (rheusis sunekhês) of eidôla-films moves extremely quickly, as Epicurus puts it "as fast as thought [hama noêmati]."11

Deleuze picks up on this description of the movement of eidôla ("as fast as thought") to support his contention that Epicurean ideas are "multiplicities of atoms." 12 Now, Deleuze would be citing opportunistically if Epicurus were simply comparing the speed of eidôla to something that also seems (at least sometimes) to occur astonishingly quickly: thinking. ${ }^{13}$ But this is no incidental comparison: the identification of eidôla with thoughts or "ideas" (Deleuzian terminology alien to Epicurus) is an essential part of Epicurean epistemology. Epicurus claims that both perceiving and thinking occur through of the action of eidôla upon percipient beings: "it is when something from the external objects [i.e. an image] enters into us that we see and think about their shapes." ${ }^{14}$ There is a continuity between perception and conception in Epicurus to the extent that both are derived from the action of

Journal of French and Francophone Philosophy | Revue de la philosophie française et de langue française Vol XXI, No 2 (2013) | http://www.jffp.org | DOI 10.5195/jffp.2013.599 
eidôla.

The notion that conception and perception are both effects of eidôla was, however, a widely derided Epicurean doctrine. Often condensed into the lapidary formula "all perceptions are true", the Epicurean proposition induces Cicero, for example, to call Epicurus a "gullible man."15 Nevertheless, the doctrine that all perceptions are true is crucial for Epicurus, since without the truth of perceptions he thinks there can be no productive reasoning, just an unintelligible morass of opinions and perceptual judgments. ${ }^{16}$ Stephen Everson's sympathetic reading of the doctrine emphasizes its dependence on the distinctive qualities of eidôla. ${ }^{17}$ "All perceptions are true" means that perceptions just are (or are reducible to) the action of eidôla on our senses. Perceived in the proper way, and prolonged into thoughts or ideas, all eidôla are "true", even when (as sometimes happens) an eidôlon's homoschematic relationship to its original is distorted. ${ }^{18}$ In fact, the occasional distortion of eidôla explains why we sometimes think and dream about non-existent creatures like Centaurs. ${ }^{19}$ Sextus Empiricus, paraphrasing an Epicurean, confirms this interpretation:

I would not say that the vision is deceived just because from a great distance it sees the tower as small and round but from near to it as larger and square. Rather I would say it is telling the truth. Because when the sense-object appears to it small and of that shape it really is small and of that shape, the edges of the eidôla getting eroded as a result of their travel through the air. ${ }^{20}$

The Epicurean truth of a perception or conception is reducible to its being the action of eidôla of a certain kind. Eidôla may no longer entirely do justice to their original, but there is no deception in their manner of acting upon us. Epicurus is reported to have claimed not just that each sense has its own proper object, a certain kind of atom, say, but also that different senses cannot refute one another "because they are not discriminatory of the same things. ${ }^{21}$ Auditory hallucinations, for instance, are not caused by pungent atoms, and so on. Epicurus wants to explain why it is that different senses do not refute or even conflict with one another by accounting for sensation as the action of eidôla. This sort of a basis for the truth of perceptions, Everson points out, is only a "disappointing result" from the point of view of "post-Pyrrhonian" expectations about the nature of truth. ${ }^{22}$ "PostPyrrhonian" here refers to a Hellenistic intellectual climate influenced by ancient skepticism, and characterized by the deeply un-Epicurean assumption that senses can and do conflict. Such conflict was taken as a given by almost all subsequent Hellenistic epistemologies, leading them to speak about perception in quite a different way - in terms of how, in light of perceptual conflict, we can say anything true (that is, perceptionindependent) about objects perceived.

Journal of French and Francophone Philosophy | Revue de la philosophie française et de langue française Vol XXI, No 2 (2013) | http://www.jffp.org | DOI 10.5195/jffp.2013.599 
When Deleuze says that ideas are problematic in Epicurus, he is tapping into this rich vein. Epicurus' association of perception and eidôla is not only provocative in the ancient context, but also widely misunderstood. Eidôla-ideas are problematic, for Epicurus, in part because they ground claims about what actually exists (the post-Pyrrhonian discourse on truth) without the specifically Epicurean truth they convey being identifiable with such claims. Herein lies the significance of the Epicurean distinction between perception-conception and opinion. While perceptions and ideas are always "true" or epistemologically primary, claims about what's really out there, the sources of the potentially distorted images, can be false. In fact, only such claims can be false: "Falsehood [pseudos] or going-astray [diêmartêmenon] always comes from an added opinion [en tô prosdoxazomenô]." ${ }^{23}$ For Epicurus, "added opinions" have a strictly negative sense. At best, they report while adding nothing to perception, and at worst they introduce falsehood into the perceptual-ideational loop. But in a remarkable reversal of philosophical discourse, what Epicurus calls "truth" itself comes to have a negative sense already by the time of Cicero, and for the subsequent Hellenistic tradition generally, which refuses to connects the truthconditions of propositions to the activity of mysterious eidôla. The doctrine of eidôla tells the subsequent Hellenistic epistemological tradition nothing about the sort of truth it comes to be interested in. The doctrine just looks like a physical postulate. ${ }^{24}$ Everson reminds us that the sort of epistemological claims which Epicurus relegated to opinion (claims about enduring objects in an intersubjective world) eventually became the primary interest of mainstream epistemology. What Epicurus called the objects of opinion become the definienda of a new "post-Pyrrhonian" conception of truth. In other words, after Epicurus (perhaps as a consequence of the development of Stoic propositional logic), the primary bearer of truth-value becomes a doxa, what modern thought identifies as a belief, opinion, proposition, representation or judgment. For Epicurus, on the contrary, the eidôlon is the primary truth-value bearer, and such a thing cannot be false, although it is susceptible to incorrect beliefs or judgments by the hasty, usually non-Epicureans.

Given this historical reversal in the discourse on truth, the Epicurean characterization of ideas as multiplicities of atoms alone does not entirely explain Deleuze's appropriation of Epicurean physics. Since at this point Deleuze links the characterization of ideas as multiplicities to the Epicurean doctrine of eidôla (without of course deriving the former from the latter), ${ }^{25}$ and this doctrine already has a negative status in the epistemological tradition (meaning not only that it tends to be scoffed at but that it tells us nothing about truth differently understood), to say that ideas are multiplicities of atoms cannot help but sound like a negative claim about the indeterminacy of ideas from the point of view of what Epicurus called opinion, but what Cicero thinks of as knowledge. Deleuze, in contrast, wants to offer an account of the determination, and in fact self-determination, of

Journal of French and Francophone Philosophy | Revue de la philosophie française et de langue française

Vol XXI, No 2 (2013) | http://www.jffp.org | DOI 10.5195/jffp.2013.599 
problematic ideas, in contrast with Kant. ${ }^{26}$ And, he thinks, so does Epicurus. Since Epicurean and post-Pyrrhonian conceptions of the relation between truth and opinion are talking past one another, then understanding one conception (the Epicurean) from the point of view of the other (postPyrrhonian) requires evaluating the former according to the extrinsic requirements of the latter. Happily, however, Deleuze discovers that the Epicurean theory is richer. Epicurus does not just recognize that multiplicities of atoms are eidôla, the Epicurean equivalents of problematic ideas, the supposed truth-value of which is hard to assess (or indeterminate) from the point of view of a post-Pyrrhonian framework. Epicurus also claims that his problematic ideas possess an immanent mechanism of selfdetermination. Since Epicurean Ideas are multiplicities of atoms, their problematicity depends on the existence of a theory of the immanent selfdetermination of atoms. Deleuze reads the Epicurean swerve as playing precisely this role:

it is indeed essential that atoms be related to other atoms at the heart of structures that are actualized in sensible composites. In this regard, the clinamen [swerve] is by no means a change of direction in the movement of an atom, much less an indetermination testifying to the existence of a physical freedom. It is the original determination of the direction of movement, the synthesis of movement and its direction which relates one atom to another. ${ }^{27}$

No text attributed to Epicurus referring to the atomic swerve survives, but reliable reports imply there was such a text. ${ }^{28}$ Although both Diogenes of Oinoanda and Cicero suggest that Epicurus introduced the swerve to avoid the necessitarian implications of Democritean atomism, Deleuze does not discuss the swerve in the context of a reconstruction of ancient Greek theories of fate. ${ }^{29}$ In fact, he thinks that the essential thing about the swerve is not the indeterminacy it introduces into the Epicurean universe, either as a discovery of free will ${ }^{30}$ or as the justification of the irreducibility of mental states to physical ones, ${ }^{31}$ but rather the intrinsic determination of a relation between atoms. Since ideas are multiplicities of such atoms, the intrinsic determination of atomic compounds should provide a theory of the immanent operation of problematic ideas - the "treasure" hidden in Epicurean atomism. ${ }^{32}$

Lucretius offers basically two arguments for the swerve, one cosmological and one libertarian. ${ }^{33}$ Deleuze's appropriation of the swerve depends on the first. Here it is:

when these bodies [atoms] are being drawn downwards by their own weight straight through the void, at totally uncertain times and uncertain places [incerto tempore ... incertisque locis] they turn aside a little in space, just so 
much that you could call their motion changed. Because if they were not accustomed to swerve [nisi declinare solerent], everything would fall downwards through the deep void, like drops of rain, no collisions would occur and no blows be effected among the atoms: nature would not have created anything. ${ }^{34}$

If this argument is taken, as it is sometimes, to show the necessity of a first creative swerve at the origin of the universe then it is actually at odds with what both Epicurus and Lucretius say elsewhere: that the universe is temporally infinite, has no beginning and that its motion is perpetual. ${ }^{35} \mathrm{~A}$ better way to understand the swerve then is not as an explanation of how collisions began, but of why there are generative collisions at all. ${ }^{36}$ Epicurus is probably responding, as he often is, to Aristotle's criticisms of Democritus. Democritus said that all motion is "forced" or occurs through collisions among atoms and that the atoms themselves have no "natural motions." Consequently, Aristotle complains that Democritus provides no arkhê, or principle, for atomic collisions - not a temporal arkhê (literally, a beginning) but arkhe in the sense of a governing inner principle or "nature." ${ }^{38}$ Democritus has no answer to the question: why are atoms the sort of thing that collide? Epicurus responds to Aristotle by improving on Democritus in two ways. First, he attributes weight to atoms as a natural motion, that is, the tendency to move, if unimpeded by other atoms, at an extremely fast speed through the void ("as fast as thought"). ${ }^{39}$ Second, Epicurus attributes to atoms the swerve, the tendency to collide (Lucretius says the atoms declinare solerent, "have a tendency to swerve") even though you'd think atoms moving along parallel trajectories would persist in parallel, laminar movement.

This reading of the swerve corroborates Deleuze's claim that its purpose is to explain, or provide a figure for, the self-determination or "reciprocal determination" of atomic compounds: "the clinamen is the reciprocal determination which is produced in a "time smaller than the minimum continuous time thinkable"." 40 Deleuze makes a similar remark in "Lucretius and the Simulacrum", where he calls self-determination "synthesis":

we must conceive of an originary direction for each atom, as a synthesis which would give to the movement of the atom its initial direction, without which there would be no collision. This synthesis is necessarily accomplished in a time smaller than the minimum of continuous time. This is the clinamen. ${ }^{41}$

So far, Deleuze's reading is quite conventional: the doctrine of clinamen is supposed to respond to Aristotle by explaining the relation of atoms with one another in terms of an internal tendency. But why does Deleuze

Journal of French and Francophone Philosophy | Revue de la philosophie française et de langue française

Vol XXI, No 2 (2013) | http://www.jffp.org | DOI 10.5195/jffp.2013.599 
introduce these considerations about the speed at which the determination of a relation among atoms (the swerve) takes place? We must chase down Deleuze's allusions.

The phrase that appears in Difference and Repetition in inverted commas, "time smaller than the minimum of continuous time thinkable", appears to be a quotation (although it is not), and in "Lucretius and the Simulacrum" Deleuze refers to the Letter to Herodotus, sections 61 and 62. Now, section 61 is all about the movement of atoms in the void. Epicurus claims all atoms move at an equal speed through the void because the void offers no resistance. Furley calls this motion at "atomic speed", 42 and Epicurus says here that it occurs "as fast as thought." Section 62, in contrast, is about the (so to speak) statistical or molar movement of atoms in compounds. Epicurus tries to reconcile the facts that some compounds move faster than others and that atoms in these compounds are all moving equally fast. Epicurus presents a tricky passage where he either relies on or defines two units of time, neither of which corresponds to Deleuze's "minimum of continuous time thinkable." Compounds manifestly move at different speeds, but atoms all move equally fast because:

atoms in compounds are moving in one direction in a minimum of continuous time [kata ton elakhiston sunekhê kronon], and not in one [direction] in times distinguishable by reason [kata tous logo theôrêtous kronous], but they frequently collide until the continuity of their motion becomes perceptible. $^{43}$

Epicurus mentions a minimum of continuous time and what seems to be a minimum of thinkable time, but not a "minimum of continuous thinkable time." Deleuze has conflated these two times in Epicurus, and their corresponding speeds. This conflation is by no means fatal to Deleuze's argument about the swerve (which Epicurus is not talking about here anyway), but it does present a challenge to grasping his point.

Epicurus' second unit of time is easier to deal with: the speed of atoms in "times distinguishable by reason" appears to be equivalent to the "atomic speed" of atoms through the void, where they move as fast as thought; both descriptions refer to the speed of atoms themselves, not the speed of compounds. The other unit, the "minimum of continuous time", seems like it should be equivalent to a minimal quantum of time, since Epicurus uses the same word (elakhiston) to denote this time and the minimum of magnitude. ${ }^{44}$ But that can't be correct. It doesn't make sense to say that a temporal minimum is defined by the slowed down movement of atoms in compounds, because it remains possible to conceive of a smaller time, or a quicker motion, namely, that of the unimpeded atom. The true minimum of time, the smallest conceivable, can only be formally defined as how long it takes an unimpeded atom to travel one spatial minimum. And indeed, so 
great an authority as Furley denies that Epicurus could be referring to a true minimum when he says "minimum of continuous time." Rather, Furley thinks, what Epicurus calls "times discernable by reason" refer to true minima of time: "the times which are distinguishable only in thought are indivisible units of time-periods of time, of course, not instants or limitswithin which an atom 'has moved' (for you can never say 'it is moving') over an indivisible unit of space." 45

Furley's reference to the Aristotelian distinction between "is moving" and "has moved", between kinêsis (movement or change) and kinêmata (jumps, or literally "having moveds"), hints at how we should resolve Deleuze's confusion. ${ }^{46}$ What Epicurus calls an "elakhiston of continuous time" is not the same as an "elakhiston of time" full stop. Epicurean time, like motion and magnitude, is fundamentally discontinuous. A minimum of continuous time must be, Furley says, a "multiple" of true minima, more like an atom of time than a true minimum (since a minimum implies discontinuity). ${ }^{47}$ If this is so, then what immediately follows the tricky passage in Epicurus makes sense: "For the added opinion about the imperceptible-that the time which can be distinguished by reason will allow for continuous movement-is not true of such things." ${ }^{48}$ That is, it is erroneous to think that continuous time (or movement) can produce discontinuous time (or movement). In fact, the opposite is true: there seems to be continuity at the level of perceptible bodies, but the discontinuous movements and times accessible to reason refute such continuity.

Sadly, Deleuze has transferred the word "continuous" into his discussions of Epicurean atomic motion where it does not belong. It is not the case for Epicurus, as Deleuze claims, that the "minimum of continuous time refers to the apprehension of thought." ${ }^{49}$ But it would be fair to say that the true minimum of discontinuous time does refer to the apprehension of thought; that is, it can only be thought, and has to be thought, to explain the apparent continuity of molar movement. Luckily, Deleuze's error is not fatal to his claims about the swerve or the existence of genuinely problematic ideas in Epicureanism, because it merely misses an Epicurean distinction that is not central to Deleuze's argument: there are not two velocities of atoms in Epicureanism, as Deleuze thinks (the continuous speed of thought and the faster speed of the swerve); there are three (the continuous speed of opinion, the discontinuous speed of thought, and the even faster speed of the swerve). What Deleuze explicitly says-that the swerve, as a determination of the relation between atoms, is accomplished faster than a minimum of continuous time-is true but trivial, since for Epicurus the continuous time of opinion is slower than even the time of thought. But what Deleuze wants to say is far from trivial: that the determination of a relation among atoms is accomplished even faster than the smallest time determinable by reason-faster than the true minimum of time, not just faster than opinion but "faster than thought." Deleuze thus means that the 
swerve stands for a "third speed of the image" (as Melinda Cooper has aptly pointed out ${ }^{50}$ ), faster than both the image of opinion (continuity) and the eidôla of thought (discontinuity).

\section{Good and Bad Infinities}

"Lucretius and the Simulacrum" expands on the idea that the swerve accomplishes an intrinsic reciprocal determination of atoms in a time smaller than the temporal minimum, or an originary synthesis of atomic motion, by introducing the related claim that Epicurean atomism entails distinguishing the true from the false infinity:

What is essential to physics is to be found in the theory of the infinite, and of the spatial and temporal minima ... [and] this fundamental object of physics: to determine what is really infinite and what is not, and to distinguish the true from the false infinite. ${ }^{51}$

According to Deleuze, the implicit Epicurean doctrine of infinities has everything to do with the theory of minima (or infinitesimals) and their relation to a prior determination that occurs through the swerve. Deleuze is aware of how the theory of indivisible minima is linked to an intuition that has been labeled "proto-calculus", as he remarks, "It is not surprising that Epicurus makes use here of the vocabulary of exhaustion: there is something analogous in the clinamen to a relation between the differentials of atoms in movement." ${ }^{52}$ I take the phrase "differentials of atoms" to be approximately equivalent to elakhista or minima. Thus Deleuze implies that the theory of swerve as the relation between minima provides answers to questions about how they are related. David Konstan has influentially argued that the majority of such questions (e.g. how do minima abut one another, if not by means of limit-entities?) are badly posed from the Epicurean point of view, since they imply that the relation takes place in terms of the actuality of a mathematical state of affairs. ${ }^{53}$ As we shall see, Deleuze claims in contrast that the relation of the differentials of atoms does not have the character of an actuality, but that the relation between minima in the swerve has the ontological status of a virtual event.

But how does the Epicurean theory of infinitesimals relate to the distinction between true and false infinity? Deleuze's attitude toward interpretations of calculus provides an instructive parallel. If Deleuze thinks that the relation $d y / d x$ (differentiation) is an example of a "pure relation" that determines itself immanently, and that consequently the differential relation is prior to the primary function of which it is supposed to be "derivative", 54 then the primary function itself must be derived, or better generated, by an operation inverse to differentiation. This is integration, an operation typically understood as early as the seventeenth century as a "process of summation in the form of a series." ${ }^{55}$ Now, the idea of summing

Journal of French and Francophone Philosophy | Revue de la philosophie française et de langue française Vol XXI, No 2 (2013) | http://www.jffp.org | DOI 10.5195/jffp.2013.599 
infinitesimals is unattractive for a number of reasons (for example, the summation of indeterminate entities like $d x$ to generate a determinate function looks question-begging), and it was replaced in the "discretizing" programme of Weierstrass and others by the notion of summing limitentities. ${ }^{56}$ Nevertheless, as late as 1981 Deleuze expresses admiration for the idea of summing infinitesimals in order to generate functions from the differential relation. Deleuze considers this sense of integration to involve a novel formulation of infinity (novel in the sense of distinct from the inexhaustible infinity of classical geometry): integration shows that in the primitive function "something finite consists of an infinity under a certain relation." Under the influence of this novel infinity, Deleuze says, the calculus attains an "equilibrium point, for seventeenth-century thought, between the finite and the infinite, by means of a new theory of relations." ${ }^{57}$ This new theory of relations is what Deleuze is looking to extract from different contexts and fields of inquiry. It is, for instance, the "treasure" hidden in the "barbaric" interpretations of the calculus and again in the Epicurean swerve.

Deleuze sees a similarly novel "theory of relations" afoot in Epicurean atomism, along with an allied novel sense of infinity. While the differential aspect of the new theory of relations is embodied in the figure of the swerve, the integral aspect appears in a notion of the infinite sum analogous to the barbaric interpretation of integration. For Epicurus:

Nature must be thought of as the principle of the diverse and its production ... Nature as the production of the diverse can only be an infinite sum, that is, a sum that does not totalize its own elements. Nature is not collective ... it expresses itself through 'and' and not through 'is'.... things exist one by one, without any possibility of their being gathered together all at once. ${ }^{58}$

Epicurus does not quite say what Deleuze attributes to him, but he comes close. Epicurus does identify the universe with an infinite number: "in terms of the number of atoms and the magnitude of the void, the universe [to pan] is infinite." ${ }^{59}$ For Deleuze, the intrinsic self-determination of the problematic idea implies or requires this sense of an infinite sum that doesn't entail unity or totality, just as the extrinsic determination of the problematic idea implies or requires the presupposition of a "systematic unity of Nature", the World, which is even, in the case of Kant, conceived of as an infinite limit: "an infinite determination in relation to the concepts of the understanding." 60 Infinity without totality, on the other hand, presupposes the swerve as a kind of positive indeterminacy_- a vagueness that isn't a function of limited understanding — which Deleuze identifies with "the irreducible plurality of causes or causal series, and the impossibility of bringing causes together into a whole." ${ }^{61}$ Infinity understood as a curative for holism is what Deleuze calls the "true infinity" advocated by Epicurus, and the swerve its embodiment.

Journal of French and Francophone Philosophy | Revue de la philosophie française et de langue française

Vol XXI, No 2 (2013) | http://www.jffp.org | DOI 10.5195/jffp.2013.599 
Nature is truly infinite when the swerve stands for the unthinkability of "Nature as a whole."

What then is Epicurus' "false infinity"? Above all, Epicurus thinks we should not regard as infinite "every worldly or intra-worldly combination," 62 even the compound of atoms we call the cosmos: "one must believe that the cosmoi, and every finite compound which is similar in form to those which are frequently seen, have come into being from the infinite ... and that all are dissolved again." ${ }^{\prime 63}$ Embracing a position criticized by Aristotle in On Generation and Corruption, Epicurus holds that the only sense of creation and destruction can be that of finite modes, becoming finite in birth and becoming infinite in death, so to speak. ${ }^{64}$ For example, Epicurus says, the percipient soul is just a compound of atoms in the world, finite and thus subject to losing the unity and identity characteristic of finitude but not infinity, in other words subject to disaggregation. ${ }^{65}$ But Deleuze points out how for Epicurus illusions predicated on falsely attributing infinity to a merely intra-worldly combination produce suffering and psychic disturbance among humans. ${ }^{66}$ For instance, the illusion of the infinite duration of the soul and the possibility of an infinitely long punishment after death is of this kind. ${ }^{67}$ Epicurean physics has the moral purpose of divesting people of such mystifications by destroying the false infinity they presuppose.

But how does Epicurus explain why people have a false sense of infinity in the first place? According to Deleuze's innovative reading, the illusions of false infinity are consequences of the extreme speed at which eidôla are propagated. Like Kantian transcendental illusions, Epicurean false infinities are internal to perception-cognition itself. Eidôla impact the senses in a "time discernable to reason alone," and thus at a speed faster than a "minimum continuous time." ${ }^{68}$ Deleuze equates the latter with a "minimum of sensible time." Since eidôla are not perceivable as such, one is only aware of perceiving permanent external objects. But the permanency of such objects is, for Epicurus, a function of opinion: we believe we see permanent objects or continuous motion, but we see eidôla. Because of the way perception, cognition and opinion divide their labor, Deleuze says, it is common for the illusions of false infinity to arise: "In virtue of their speed, which causes them to be and to act below the sensible minimum, simulacra produce the mirage of a false infinite in the images they form." ${ }^{19}$ When one sees something (say, in a dream) that looks like a divine being or a terrifying human-animal hybrid, although it is a product of the motion of imperceptibly fast images and not a real, abiding object, opinion steps into its habitual role and ascribes existence and permanence to the simulacral object. ${ }^{70}$

Deleuze's contrast between true and false infinities, and the treatment of Epicurean nature as an infinite sum without totality, enhances his discussion of problematic ideas. Epicurean false infinity hinges on the fact that simulacra move "as fast as thought" and no faster. False Epicurean infinity

Journal of French and Francophone Philosophy | Revue de la philosophie française et de langue française Vol XXI, No 2 (2013) | http://www.jffp.org | DOI 10.5195/jffp.2013.599 
remains with minima, elakhista, infinitesimals (the Epicurean equivalents of the undetermined $d x$ ), without advancing to an understanding of the positive role of the clinamen (equivalent to the differential relation $d y / d x$ ), that describes the intrinsic determination of difference in itself. What Epicurus denounces as false infinity is the ancient Greek counterpart of what Deleuze rejects as "extrinsicism", 71 in which problematic ideas are understood from the point of view of something external to them - in the case of Kant, possible experience and what Deleuze calls "representation"; in the case of Epicurus, "added opinion."

But Deleuze's distinction between true and false infinity is oddly Hegelian. Is it out of keeping with Deleuze's well-known criticisms of Hegel in Difference and Repetition ? $^{72}$ There appears to be an important contrast between Deleuze in 1961 ("Lucretius and the Simulacrum") and in 1968 (Difference and Repetition). In the latter, far from affirming a true infinity, Deleuze argues that a rejection of Kantian extrinsicism requires a rejection of the distinction between finite and infinite along with the false question of whether infinitesimals are real or fictional. ${ }^{73}$ The distinction is false because the relationship between infinitesimals is a problematic idea, and hence a way of letting difference think for itself, and "the entire alternative between finite and infinite applies very badly to difference." ${ }^{74}$ In Difference and Repetition, "infinite" and "finite" merely describe an oscillation internal to representation, the systole and diastole of its variable comprehension: "infinite and finite are indeed characteristics of a representation in so far as the concept that it implicates develops all its possible comprehension or, on the contrary, blocks it." ${ }^{\prime 75}$ Here infinity inevitably means infinite representation tied to a conception of possibility as the exceedingly great extent to which a concept's form of identity can be stretched. ${ }^{76}$ In "Lucretius and the Simulacrum", on the other hand, Deleuze recognizes two infinities one associated (as I have argued) with the infinity of representation and the extrinsicism of the Kantian Idea, and the other associated with the nature of the problematic idea in its intrinsic development. Despite the consistency of Deleuze's oeuvre, he vacillates on the topic of infinity. In Difference and Repetition it sounds like infinity as such cannot escape from representation. That book is silent about the other kind of infinity, associated with the selfdetermination of problematic ideas, and the speed of the synthetic activity of the atomic swerve that relates infinitesimals.

\section{Deleuze and Guattari's Epicurean Formalization of Problematics}

Given the underlying parallels between Difference and Repetition and "Lucretius and the Simulacrum", and despite the discrepancy on the topic of infinity, we should expect Deleuze to distinguish between good and bad infinities on his own behalf and to advocate the former. This is precisely what he and Guattari do in What is Philosophy? (1991), a book that makes 
Deleuze's debt to Epicurus even clearer. What is Philosophy? presupposes a relationship between thought and infinity. As Deleuze and Guattari put it: "Thought demands 'only' movement that can be carried to infinity. What thought claims by right, what it selects, is infinite movement or movement of the infinite. It is this that constitutes the image of thought." ${ }^{77}$ Such an image of thought is distinct from the dogmatic image Deleuze criticizes in Difference and Repetition, which is theorematic, extrinsicist and often inspired by negativity. What is Philosophy? contains the formalization of an alternative image of thought, which conceives of ideas as problematic and intrinsically self-determining. And, to the extent that thought is related to infinity in terms of speed, Deleuze and Guattari's new image of thought has an explicitly Epicurean inspiration: "From Epicurus to Spinoza ... the problem of thought is infinite speed." ${ }^{78}$ While Spinoza is discussed elsewhere a number of times in What is Philosophy?, Epicurus is not. The derivation of the book's theses from Epicurus remains implicit. Here I shall make it explicit.

The notion of infinite speed is basically the crux of What is Philosophy? Deleuze and Guattari identify infinite speed, in turn, with chaos: "Chaos is defined not so much by its disorder as by its infinite speed with which every form taking shape in it vanishes." ${ }^{\prime 79}$ Deleuze and Guattari continue, in terms that recall Difference and Repetition, Logic of Sense and the Epicurean theory of generation and destruction: "[chaos] is a void that is not a nothingness but a virtual ... without consistency or reference ... Chaos is the infinite speed of birth and disappearance." 80

Crucially, the infinity that Deleuze and Guattari accept and affirm in What is Philosophy? is a virtual infinity. What does this mean? Virtual infinity is the figure through which Difference and Repetition and "Lucretius and the Simulacrum" are reconciled. In Difference and Repetition, virtuality refers to the internal differentiation of the problematic idea, effected by intrinsic or immanent mechanisms, which is opposed to the interpretation of ideas in terms of possibilities (e.g. as impossibilities, something Deleuze considers to be implicit in Kant). ${ }^{81}$ Deleuze thinks that the difference between possible and actual states or objects is not a strong enough modal difference to ground a philosophy of difference in itself. Aristotle's terms "possible" and "actual" describe modes of one identical concept (some one thing), to which an existential quantifier is applied in the case of the actual and denied in the case of the possible. ${ }^{82}$ Deleuze wonders, "What difference can there be between the existent and the non-existent if the non-existent is already possible, already included in the concept ... Existence is the same as but outside the concept." If one begins with this style of thinking about possibility, it turns out that "difference can no longer be anything but the negative determined by the concept." ${ }^{83}$ The determination of difference as negative is the great drawback of the discourse on possibility. The virtual state of the elements of problematic ideas is not similar, Deleuze says, to a supposed possible state. Fundamentally, this is because virtualities are not 
'unreal' (in the sense of lacking actual existence): "The virtual is opposed not to the real but to the actual. The virtual is fully real in so far as it is virtual. ... [It is] 'real without being actual, ideal without being abstract'." ${ }^{84}$ The difference between virtuality and actuality (between problematic idea and real experience), as opposed to the discourse on possibility, is adequate to theory difference in itself. Virtual and actual are different in kind, but such a difference in kind is not connected to the presence or absence of reality or existence: "it is difficult to understand what existence adds to the concept when all it does is double like with like. Such is the deficit of the possible." 85 The same sense of virtuality is obviously intended in What is Philosophy?, where the philosophical concept is said to be "real without being actual, ideal without being abstract." 86

Just as infinity is affirmed in What is Philosophy? (as the infinite speed of the virtual), in contrast with Difference and Repetition, the term "concept" has also changed its sense. Deleuze and Guattari memorably define philosophy as the creation of concepts, but such concepts are not understood, as they are in Difference and Repetition, as applications, with greater or lesser extension, of a given form of identity. ${ }^{87}$ This is the case in the earlier book seemingly because it treats concepts solely as Aristotelian universals or as Kantian categorial concepts of the understanding. ${ }^{88}$ In contrast, in What is Philosophy? concepts are the proper subset of problematic ideas endemic to philosophy. Concepts are specifically "philosophical Ideas", one of at least three kinds of "creative ideas", the other two belonging to science and art. ${ }^{89}$ To put it another way, concepts are the philosophical manner in which problematic ideas are meant to determine themselves intrinsically. Deleuze and Guattari describe concepts in a variety of suggestive ways: a real concept is an "incorporeal" that does not refer to a state of affairs but "speaks the event, not the essence of the thing." 90 The concept of a bird, for instance, does not refer to the specific or generic essence (e.g. "blue jay" or "corvidae"), but the "composition of its postures, colors, and songs: something indiscernable that is not so much synesthetic as syneidetic." ${ }^{91}$

This conception of concepts is quite far from the extension of a preexistent identity or essence. Deleuze and Guattari do say, however, that a concept is the "condensation" or gathering together of heterogeneous elements (postures, colors, etc.). The Deleuzoguattarian concept is defined as "the inseparability of a finite number of heterogeneous components traversed by a point of absolute survey at infinite speed." And "survey", they explain, means the "specific infinity" of the concept's state. ${ }^{92}$ What should we make of the totalizing operation of creating a concept, on the one hand, and the reference to infinity, on the other? According to Deleuze and Guattari, concepts gather variations like this on account of the specific relation of philosophy to chaos (i.e. virtual infinity or infinite speed): "philosophy wants to know how to retain infinite speeds while gaining consistency, by giving the virtual a consistency specific to it." 93 In other words, philosophy wants to emulate 
virtual infinity but in a less "dissipative" manner, ${ }^{94}$ preserving the diverse elements that would otherwise vanish. It does so, in part, by creating concepts that gather together heterogeneous variations (e.g. of colors, postures, etc.) into a whole (still "fragmentary" because it is not a finished totality that coheres through a form of identity), which is in turn identified with the "specific infinity" of the concept (e.g. blue jay). Deleuze and Guattari adopt Epicurean language to say that philosophy "selects infinite movements of thought and is filled with concepts formed like consistent particles going as fast as thought." 95

But creating concepts is not all that philosophy does. If it were, then philosophy would remain open to the criticism that it merely approximates virtual infinity in an extrinsic manner, by asymptotally comparing an extremely fast but finite conceptual speed with the truly infinite speed of chaos. By retaining the Epicurean terminology and saying that the conceptual approximation of virtual infinity moves "as fast as thought", Deleuze and Guattari imply that virtual infinity itself moves faster than thought, at "swerve-speed" rather than "atomic speed", so to speak. In both calculus and Epicureanism, Deleuze thinks, an account of the problematic as undetermined is supplemented by its self-determination. Both $d y / d x$ and the clinamen are specific incarnations of, or ways of thinking about, a primordial mechanism of relation or relatedness that precedes the diversity of relata.

So what do Deleuze and Guattari mean by speed? Speed should be understood as the speed of becoming. Since in The Logic of Sense Deleuze explicitly identifies events with Platonic "becomings", 96 the fact that a concept "speaks the Event" by emulating infinite speed suggests that becoming occurs at infinite speed. Commentators sometimes attempt to describe Deleuze's (or Deleuze and Guattari's) philosophy as promoting the priority of "relation" over the terms or self-identical things related. ${ }^{97}$ That is to say, roughly, a "thing" is just a local, relatively stable system of relations, and not the embodiment of an essence whose identity belongs to it as a first principle. Rather, a thing has had to become identical, to become what it is, and is thus subject to a becoming, which is "prior" to its identity. In the old philosophical contrast between being and becoming, being always means the being of some one thing. ${ }^{98}$ Rather than "relation", Deleuze and Guattari talk about "speed." The virtue of this approach lies in the fact that while the speed of a being is necessarily finite the speed of becoming is not. Becoming must only be said to occur at a calculable, finite rate if it is assumed that becoming is something that happens to beings already given, in terms of which becoming is measured. But Deleuze's difference is not the difference between two things, but the difference that produces things, whose selfidentity is just a relative not an absolute determination.

Deleuze and Guattari describe the primacy of pure becoming as "infinite speed" because although becoming means a movement, it is not the movement of some thing (in the sense of some one thing). Deleuze and

Journal of French and Francophone Philosophy | Revue de la philosophie française et de langue française 
Guattari's "infinite speed" does not mean an actual being accelerated to an unlimited velocity (something inconceivable). To call the speed of becoming infinite is to submit to a paradoxical expression, to the extent that the speed of becoming is incalculable in terms of a finite framework. It is called infinite, because it has no finite speed. If "speed" means calculable speed, then becoming has no speed; if "speed" does not mean calculable (finite) speed, then the speed of becoming is infinite. As we shall see, Deleuze and Guattari contrast infinite speed with the very fast but finite speed involved in calculating the actual speeds of self-identical things (which they call "actualities").

To put it otherwise, Deleuze and Guattari's "infinite speed" means faster than the minimum time conceivable (a time minimum), and a fortiori faster than the fastest physical movement. In Epicurean terms, infinite speed means "faster than atomic speed." Concretely, this entails that movement at infinite speed has always already occurred whenever we isolate what we believe to be a conceptual or physical minimum. The identifiable minimal things (possessing unity, identity, etc.) that we are able to isolate have always become identifiable, in the extreme, at an infinite speed. And Deleuze and Guattari credit Epicurus, and the notion of swerve, with discovering this kind of speed (so long as we understand the swerve not to mean just a relation between already self-identical atoms, but the fact that the motion of atoms is always tending to change, to become different, before it can be determined, assigned a calculable speed or direction). Finally, Deleuze and Guattari call infinite speed virtual because they want to claim it is something real, but not something that should be understand in terms of an external framework (which would be actual). Becoming-different occurs at a virtual, infinite speed because (like the swerve) it describes the way that apparently unified and self-identical things are only determined as unified and selfidentical according to external criteria, but genuinely possess the internal power of determining themselves, which describing them in terms of their actual existence and self-identity obscures or ignores.

For Deleuze and Guattari, philosophy's creation of concepts is always accompanied by the correlative constitution of what they call a "plane of immanence", a "secant plane" of virtual infinity, or a section of chaos. ${ }^{99}$ The best way to understand the plane of immanence is as a way of making explicit what remained all-too-implicit in the discussion of problematic ideas in Difference and Repetition, that it is crucial for problematic Ideas to be allowed to determine themselves immanently, that is, in an intrinsic way, rather than being determined by some external agency or evaluated according to external requirements. What Deleuze calls "representation" means the pervasive application of extrinsic requirements to the problem, and it returns in What is Philosophy?:

Philosophers have not been sufficiently concerned with the nature of the concept as philosophical reality. They

Journal of French and Francophone Philosophy | Revue de la philosophie française et de langue française

Vol XXI, No 2 (2013) | http://www.jffp.org | DOI 10.5195/jffp.2013.599 
have preferred to think of it as a given knowledge or representation that can be explained by the faculties able to form it (abstraction or generalization) or employ it (judgment). ${ }^{100}$

The creation of concepts, in contrast, is not the function of a faculty or indeed any unilateral action of thought on something outside it. Rather, the creation of concepts depends on their "self-positing" or "autopoetic characteristic." The requirement that concepts have this characteristic is equivalent to the requirement that theories of problematic ideas shift from being extrinsicisms to intrinsicisms, and it is formalized in the figure of the plane of immanence: "there is philosophy wherever there is immanence."101

The Epicurean plane of immanence carries movement to an infinite speed-faster than the fastest thinkable speed (which would be the discontinuous traversal of one minimum of magnitude in one minimum of time) to a speed "faster than thought." While the speed of a concept is the speed of thought, this remains nevertheless a specific infinity, an approximation of an even faster speed, associated with the autopoetic selfpositing of problems, and described in Epicureanism in terms of a mechanism of relation or synthesis anterior to relata (which is Deleuze's interpretation of the clinamen). Deleuze suggests that such a vision of philosophy inaugurates a new theory of relations or image of thought, the alternative to the dogmatic image that Deleuze sought to articulate throughout his career. There is no doubt that this image of thought has a profoundly Epicurean inspiration. The entirety of What is Philosophy? is devoted to the formalization of such an alternative. The formalization starts with the notion of virtual infinity (or chaos), which is sectioned by three different planes (corresponding to philosophy, science and art, respectively). The philosophical plane-section is a plane of immanence that attempts to render consistent the virtuality of the infinite, which means doing justice to the tendency of problems to determine themselves in novel ways.

The chaotic image of thought in What is Philosophy? has a profoundly Epicurean inspiration, but not an exclusively Epicurean one. To the extent that the discussion of speed resonates with Deleuze's conception of virtual multiplicities, it is inspired by a reading of Henri Bergson and Bernhard Riemann. A comparative reading of the concept of speed as it is at work throughout Deleuze and Guattari's A Thousand Plateaus also reveals contributing intertexts, for example, the ethnographical works on nomadic cultures that Deleuze and Guattari use to motivate their "Nomadology", and Paul Virilio's political thesis in Speed and Politics that the political state is a filter or regulator of speeds associated with the rebellious masses, among others. $^{102}$ In What is Philosophy? Deleuze and Guattari also remark that the problem of infinite speed engages the philosophy not just of Epicurus but of Spinoza. Epicurean physics is one source among many for the "dromological" (to borrow a term from Virilio) metaphilosophy developed

Journal of French and Francophone Philosophy | Revue de la philosophie française et de langue française Vol XXI, No 2 (2013) | http://www.jffp.org | DOI 10.5195/jffp.2013.599 
in What is Philosophy? Nevertheless, the specific form that the discussion of speed takes (in terms of infinity and chaos) is best understood in light of the references to Epicurus.

\section{Conclusion: Infinite Speed is Not Very Fast Finite Speed}

The discussion of infinite speed in What is Philosophy? has at least one direct application. While Deleuze and Guattari's meta-philosophical conception of philosophy is clearly Epicurean in inspiration, their conception of the relation between philosophy and science is equally clearly inspired by the Stoics. For Deleuze and Guattari, the correct way to explain the disciplinary and methodological differences between science and philosophy is in terms of the Stoic distinction "between, on the one hand, states of affairs or mixtures of bodies in which the event is actualized and, on the other, incorporeal events." ${ }^{103}$ While they define philosophy as the creation of concepts and of a correlative plane of immanence, science is the creation of "functions" and of a "plane of reference." ${ }^{104}$ The big difference between science and philosophy, in their view, is that scientific functions express states of affairs in the revitalized Stoic sense. Such states of affairs are "actualities, even though they may not yet be bodies or even things, units or sets." ${ }^{105}$ Philosophy, as we saw, is not concerned primarily with actualities but with virtual events: "It is a concept that apprehends the event, its becoming, its inseparable variations; whereas a function grasps a state of affairs." ${ }^{106}$ The contrast between actual and virtual returns in the neo-Stoic distinction between science and philosophy. If virtual, as I have said, refers to the internal differentiation of the problematic idea, which Deleuze has explained as something effected by immanent mechanisms of relation that are "infinitely fast" (that is, accomplished before any given thought can occur or entity exist), then what is actual? Deleuze and Guattari claim that actuality refers to the field of reference created by the sectioning of chaos characteristic of science. While philosophy creates concepts in order to emulate virtual infinity by means of the specific infinity of the concept and the "consistent virtuality" of the plane of immanence, science is characterized by a different approach. It doesn't bother trying to retain virtual infinity, but to accomplish something by relinquishing it: science "relinquishes the infinite, infinite speed, in order to gain a reference able to actualize the virtual." It accomplishes this specifically by slowing down infinite speed. Science is concerned not with the infinite speed of the virtual but the very fast speed of the actual. "To slow down,, Deleuze and Guattari say, means "to set a limit in chaos to which all speeds are subject"; that is to say, installing a limit that acts as a parameter, or extrinsic metric, to which actualities are related (what Deleuze and Guattari call a "plane of reference"). ${ }^{107}$ In contrast, the "infinite" speed of virtual infinity has the sense of a becoming that is faster than any such limit. Deleuze and Guattari's point in talking about infinite speed is that whenever a very quick but finite speed is installed as a limit and a specific field of (scientific) understanding

Journal of French and Francophone Philosophy | Revue de la philosophie française et de langue française

Vol XXI, No 2 (2013) | http://www.jffp.org | DOI 10.5195/jffp.2013.599 
emerges, any claims to understand becoming or difference from the point of view of this scientific field (in terms of actualities) is undermined by the fact that an "infinitely fast" becoming-different will already have occurred. It's no use, moreover, thinking that this sort of becoming doesn't occur, or can just be ignored. It ought, rather, to be understood as the necessary condition of actually diverse things as something real but not actual (in Deleuze and Guattari's terms "virtual"). Deleuze and Guattari's name for the moving or changing elements that are involved in the "infinitely fast" becoming, which is primary and seems from the point of view of actuality always to have already occurred, is event.

Take the concept of atomism. It can be construed in both actual and virtual terms. Epicurus' theory that the eidôla of which thought is made travel at some incredibly fast speed "atomic speed" can be seen (as I have argued) as a problematic idea in Deleuze's sense in relation to the clinamen whose velocity exceeds the speed of atoms. If this is so, then the swerve is the Epicurean figure of what Deleuze and Guattari call "virtual infinity." And insofar as this operator of pure relation or pure becoming, prior to the actuality or self-identity of elements, belongs to Epicureanism then the Epicurean concept "speaks the event," that is, it gives us a way of thinking about the nature of becoming and difference-since what is becoming but becoming-different?-in terms of infinite speed. Alternatively, in actualist terms, atoms moving at "atomic speed" may be seen as a quintessentially scientific slowing-down of infinite speed, the application of a speed-limit as a parameter for evaluating actualities. The fact that Deleuze and Guattari refer to the speed of light as one typically scientific figure by which speed is limited in the constitution of a plane of reference, combined with the fact that Lucretius compares the speed of simulacra to the speed of light, may be thought to support the second alternative. ${ }^{108}$

The scientific or actualist construal of Epicureanism, although not the final word, is not adventitious. In fact, it points toward Deleuze's main criticism of Epicurean atomism. The concept of atoms, despite Epicurus' best efforts to communicate the immanent auto-determination of the idea implied by the swerve, is all too easily construed as involving the constitution of a plane of reference. That is, the concept of atomism might not be a concept, strictly speaking, but a function referring to states of affairs. Deleuze says: "the Epicurean atom still retains too much independence, a shape and an actuality. Reciprocal determination [implied by the clinamen] here still has too much of the aspect of a spatio-temporal relation." ${ }^{109}$ Compare the criticisms of Epicurus in Logic of Sense: unlike the Stoics, the Epicureans fail to distinguish between bodies and events. Because the Epicureans use the swerve to "cleave" the causal relation in a dramatically un-Stoic way, the swerve looks like a figure of spatio-temporal or negative indeterminacy. ${ }^{110}$ In turn, this leads to interpretations of the swerve in terms of free-will or non-reductive physicalist psychology,

Journal of French and Francophone Philosophy | Revue de la philosophie française et de langue française Vol XXI, No 2 (2013) | http://www.jffp.org | DOI 10.5195/jffp.2013.599 
approaches that Deleuze would consider to be on the wrong foot.

When Deleuze and Guattari talk about infinite speed and chaos in What is Philosophy? there are Hellenistic philosophical figures and references in play. The purpose of this paper has been to explain Deleuze and Guattari's references to Epicurus and to show what the Epicurean concepts are doing in their work. To be clear, I don't think Deleuze and Guattari are thinking here exclusively about ancient philosophy, but they are interested enough in the Stoics and Epicureans for an analysis of their ancient conceptual touchstones to illuminate, for example, what Deleuze and Guattari mean by "infinite speed." Scholars have become sensitive recently to the influence on Stoicism on Deleuze's thought. The influence of Epicureanism is equally evident, but it has not been elucidated entirely. I hope this essay goes some way towards doing so.

The alternative image of thought that What is Philosophy? is designed to formalize has both an Epicurean and a Stoic inspiration. It is Epicurean in that it starts with infinite speed, which accomplishes conjunctive syntheses or relates variations, and is subsequently emulated by a plane of immanence called "nature", a totality without unity whose elements are related to one another or determined in a purely intrinsic way. The new image of thought is also Stoic, in that it presupposes a difference in kind between states of affairs (actualities, including bodies) and events (virtualities) derived from the Stoic ontological stemma. But Deleuze thinks that the Epicureans, unlike the Stoics, lack a strong distinction between events and states of affairs, so that the Epicurean figure of the immanent determination of problems (the swerve) is liable to be taken as a spontaneous physical motive force. The vast majority of the subsequent history of the reception of Epicureanism testifies to this liability. And it may be the reason why in the context of the reception of Deleuze, his important reading of Epicurus has been overshadowed by attention paid to the Stoics, who, despite defending a solid distinction between bodies and events, lack a theory of the immanent determination of problems; they lack a spectrum like speed by which to compare the consistent thinkable virtuality of events with the real chaos of their becoming.

1 Among Deleuzians, see Veronique Bergen, L'ontologie de Gilles Deleuze (Paris: L'Harmattan, 2001); Alain Beaulieu, “Deleuze et les stoïciens,” in Gilles Deleuze: heritage philosophique, ed. A. Beaulieu. (Paris: PUF, 2005), 45-72; and Sean 
Bowden, "Deleuze et les Stoïciens: une logique de l'évenement," Bulletin de la Société Américaine de Philosophie de Langue Française 15 (2005): 72-97, who all offer trenchant analyses. Among Hellenists, see Thomas Bénatouil, "Deux usages du stoïcisme: Deleuze, Foucault," In Foucault et la philosophie antique, ed. F. Gros and C. Lévy (Paris: Kimé. 2003), 17-50; John Sellars, "An Ethics of the Event," Angelaki 11.3 (2006): 157-71, and John Sellars, "Chronos and Aion: Deleuze and the Stoic Theory of Time," Collapse 3 (2007): 177-205.

${ }^{2}$ A notable exception to this generalization is Melinda Cooper, "Vitesses de l'image, puissances de la pensée: la philosophie épicurienne revue par Deleuze et Guattari," French Studies 61.1 (2002): 45-60, whose insights have enhanced my understanding of the topic.

${ }^{3}$ Gilles Deleuze, Difference and Repetition, trans. P. Patton (New York: Columbia University Press, 1994), 184.

${ }^{4}$ Deleuze, Difference and Repetition, 184.

5 Epicurus' letter is recorded in Diogenes Laertius' Lives of the Eminent Philosophers, Vol. II, ed. R. D. Hicks (Cambridge, MA: Loeb Classical Library, 1925). Translations from the Greek are mine, although I have consulted the translation in Hellenistic Philosophy: Introductory Readings, eds. B. Inwood and L. P. Gerson (Indianapolis: Hackett, 1997).

${ }^{6}$ Epicurus, "Letter to Herodotus," 46.

7 Epicurus, "Letter to Herodotus," 61-2. Of course, Epicurus admits that atoms do slow down as a function of their being offered resistance by other atoms. In compounds, the speed of atoms can vary, due to the internal non-uniformity of atoms' movement, which includes contrary motions, vibrations, etc., that slow the motion of the whole compound. Compare also Lucretius, On the Nature of Things, trans. W. H. D. House and M. F. Smith (Cambridge, MA: Loeb Classical Library, 1924), book 2, lines 152-66.

8 Epicurus, "Letter to Herodotus," 46.

9 Epicurus, "Letter to Herodotus," 46.

10 Epicurus, "Letter to Herodotus," 46. Lucretius, disanalogously, attributes the speed of images to their unsurpassed fineness, so that even when the images are not moving through a perfect vacuum, they can still travel extremely fast, and "as it were pass through [quasi permanare]" intervening compounds, like neutrinos (On the Nature of Things, book 4, lines 196-8).

11 Epicurus, "Letter to Herodotus," 48.

${ }^{12}$ Deleuze, Difference and Repetition, 184. 
13 Lucretius makes a comparison in this vein when he compares the speed of images to the speed of light (On the Nature of Things, book 4, lines 185 and 206-8).

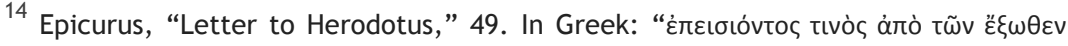

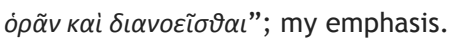

${ }^{15}$ Cicero, On Academic Scepticism, trans. C. Brittain (Indianapolis: Hackett, 2006), book 2 , section 82 .

16 Cicero attributes this argument to Epicurus twice: once in On Academic Scepticism, book 2, section 101, and once in On the Nature of the Gods, trans. $\mathrm{H}$. Rackham, in Cicero: On the Nature of the Gods and Academics (Cambridge, MA: Loeb, 1933), book 1, section 70. Compare Lucretius: “our conception of truth is derived ultimately from the senses and ... their evidence is unimpugnable" (On the Nature of Things, book 4, 478-9), and "unless [the senses] are true, all reason will also be false" (book 4, 485).

17 Stephen Everson, "Epicurus on the Truth of the Senses," in Epistemology (Companions to Ancient Thought 1), ed. S. Everson (Cambridge: Cambridge University Press, 1990), 161-83.

18 Epicurus, “Letter to Herodotus," 48.

${ }^{19}$ Lucretius, On the Nature of Things, book 4, lines 722-76.

20 Sextus Empiricus, Adversus Mathematicos libri XI, ed. Immanuel Bekker (Berlin, 1842), book 7, sections 206-9. This is Everson's translation.

21 Diogenes Laertius, Lives of Eminent Philosophers: Vol. II, trans. R. D. Hicks (Cambridge, MA: Loeb), book 10, section 32. Compare Lucretius, On the Nature of Things, book 4, lines 486-9.

22 Everson, “Epicurus on the Truth of the Senses," 179-81.

23 Epicurus, “Letter to Herodotus," 50.

24 Everson contrasts his reading of Epicurus' doctrine with others, which are, in his view, permeated by post-Pyrrhonian expectations: A. A. Long, “Aisthesis, Prolepsis and Linguistic Theory in Epicurus," Bulletin of the Institute for Classical Studies 18 (1971): 114-33; and Gisela Striker, “Epicurus on the Truth of Sense-Impressions," Archiv für Geschichte der Philosophie 59 (1977): 129-42. Long and Striker both attempt to save Epicurus' otherwise desperate position by claiming that Epicurus means that "all perceptions are real" rather than "all perceptions are true", since he must understand that perceptions are not the right sort of thing to bear a truthvalue (only propositions, judgments, doxai are), unless he makes a serious philosophical error.

Journal of French and Francophone Philosophy | Revue de la philosophie française et de langue française Vol XXI, No 2 (2013) | http://www.jffp.org | DOI 10.5195/jffp.2013.599 
My purpose here is not to give a complete characterization of Deleuze's conception of ideas as multiplicities in Difference and Repetition. There are already comprehensive accounts of this derivation of Deleuzian multiplicities: for instance, Robin Durie, "Problems in the relation between maths and philosophy," in Virtual Mathematics: The Logic of Difference, ed. S. Duffy (Manchester: Clinamen Press, 2006), and Keith Ansell Pearson, Philosophy and the Adventure of the Virtual: Bergson and the time of life (New York: Routledge, 2002), 13-18.

${ }^{26}$ Deleuze, Difference and Repetition, 169-70, 180. For defenses of this claim that I assume without defending, see Daniel W. Smith, "Deleuze, Kant, and the Theory of Immanent Ideas," in Deleuze and Philosophy, ed. C. Boundas (Edinburgh: Edinburgh University Press, 2006), 43-61; and Sean Bowden, The Priority of Events: Deleuze's Logic of Sense (Edinburgh: Edinburgh University Press, 2011), 103-15.

27 Deleuze, Difference and Repetition, 184; my emphasis.

${ }^{28}$ Cicero, "On the Nature of the Gods," book 1, sections 69 and 73; Cicero, "On Fate," trans. H. Rackham, in Cicero: On the Orator: Book 3. On Fate. Stoic Paradoxes. On the Divisions of Oratory (Cambridge, MA: Loeb, 1942), sections 22-3; Cicero, On Ends, trans. H. Rackham (Cambridge, MA: Loeb, 1914), book 1, sections 19 and 28; and Diogenes of Oinoanda, The Philosophical Inscription of Diogenes of Oinoanda, ed. M. F. Smith (Vienna: Verlag der Osterreichischen Akademie der Wissenschaften, 1996), fragment 54.

29 This is one way in which Deleuze's readings of the Stoics and the Epicureans diverge. I speculate that the divergence can be explained as follows: in The Logic of Sense, Deleuze notes that the Epicureans conceive of causality in a way that does not involve incorporeals. Consequently, Deleuze must think that in terms of fate the swerve can only stand for an indeterminate break in the causal chain, as indeed Cicero's De Fato describes it. This conception of swerve assigns it a merely negative role. See Gilles Deleuze, The Logic of Sense, trans. M. Lester and C. Stivale (New York: Columbia University Press, 1990), 6, 94, 270. On Deleuze and the Stoic conception of fate, see M. J. Bennett “Cicero's De Fato in Deleuze's Logic of Sense", Deleuze Studies (forthcoming 2014).

30 Suzanne Bobzien, “Did Epicurus Discover the Free Will Problem?” Oxford Studies in Ancient Philosophy 19 (2000): 287-339, is critical of this reading, but offers an excellent summary of the arguments for it.

31 David Sedley, “Epicurus' refutation of determinism," in $\Sigma Y Z H T H \Sigma I \Sigma$ : Studi Sull'Epicureismo Greco e Romano Offerti a Marcello Gigante, ed. G. Macchiaroli (Naples: Bibliopolis, 1983), 11-51; and David Sedley, “Epicurean Anti-Reductionism," 
in Matter and Metaphysics, ed. J. Barnes and M. Mignucci (Naples: Bibliopolis, 1988), 295-327.

32 Deleuze, Difference and Repetition, 170. Deleuze uses this expression in a discussion of the development of the calculus, which is for him the archetype of a discourse on the self-determination of problematic ideas. See: Bowden, The Priority of Events, 103, and Daniel W. Smith, “Deleuze on Leibniz: Difference, Continuity, and the Calculus," in Current Continental Theory and Modern Philosophy, ed. S. H. Daniel (Evanston, IL: Northwestern University Press, 2005), 127-47. It can be transferred without distortion to Deleuze's appropriation of the Epicurean clinamen. 33 Lucretius, On the Nature of Things, book 2, lines 216-24 and book 2, lines 251-93. 34 Lucretius, On the Nature of Things, book 2, lines 217-24; my translation.

35 Epicurus, “Letter to Herodotus," 43; Lucretius, On the Nature of Things, book 2, lines 569-80.

36 Tim O'Keefe, “Does Epicurus Need the Swerve as an Archê of Collisions?” Phronesis 41.3 (1996): 314.

37 Aristotle, “Physics," trans. R. P. Hardie and R. K. Gaye, in The Complete Works of Aristotle, ed. J. Barnes (Princeton: Princeton University Press, 1984). References to works by Aristotle will be given by an abbreviated treatise-title, followed by the marginal Bekker numbers for line reference: here, Phys. 215a1-13.

38 Aristotle, Phys. 252a32-b2.

39 David J. Furley, Cosmic Problems: Essays on Greek and Roman philosophy of nature (New York: Cambridge University Press, 1989), 101-2.

40 Deleuze, Difference and Repetition, 184.

41 Deleuze, The Logic of Sense, 269.

42 David J. Furley, Two Studies in the Greek Atomists (Princeton: Princeton University Press, 1967), 124.

43 Epicurus, “Letter to Herodotus,” 62.

44 Epicurus, “Letter to Herodotus," 58, for example.

45 Furley, Two Studies, 124.

${ }^{46}$ See Aristotle, Phys. 232a7-8.

47 Furley, Two Studies, 114.

48 Epicurus, "Letter to Herodotus," 62

49 Deleuze, The Logic of Sense, 269.

50 Cooper, “Vitesses de l'image," 47.

51 Deleuze, The Logic of Sense, 272. 
52 Deleuze, Difference and Repetition, 184. Deleuze is referring, I believe, to Epicurus, "Letter to Herodotus," 62, and the vocabulary of indivisible elakhista.

53 David Konstan, “Problems in Epicurean Physics," Isis 70.3 (1979): 394-418.

54 Deleuze, Difference and Repetition, 171-3. Deleuze uses the phrase "pure relation" in his seminar: Gilles Deleuze "Spinoza 17/02/1981," http: / / www. webdeleuze.com/php/texte.php?cle=37\&groupe=Spinoza\&langue=1. It has, nonetheless, passed into the critical literature: see Smith, "Deleuze on Leibniz," 137-39, and Simon Duffy, “The mathematics of Deleuze's differential logic and metaphysics," in Virtual Mathematics: The Logic of Difference, ed. S. Duffy (Manchester: Clinamen Press, 2006), 120-21.

55 Duffy, "The mathematics of Deleuze's differential logic," 126.

${ }^{56}$ Duffy, "The mathematics of Deleuze's differential logic," 127-9.

57 Deleuze, “Spinoza 17/02/1981."

${ }^{58}$ Deleuze, The Logic of Sense, 266-7.

59 Epicurus, "Letter to Herodotus," 41

${ }^{60}$ Gilles Deleuze, Kant's Critical Philosophy, trans. H. Tomlinson and B. Habberjam (Minneapolis: University of Minnesota Press, 1984), 20-21.

61 Deleuze, The Logic of Sense, 270.

62 Deleuze, The Logic of Sense, 272.

${ }^{63}$ Epicurus, "Letter to Herodotus," 73.

${ }^{64}$ See Aristotle, On Generation and Corruption, 316b35.

${ }^{65}$ Epicurus, “Letter to Herodotus," 64-5.

${ }^{66}$ Deleuze, The Logic of Sense, 273.

${ }^{67}$ Lucretius, On the Nature of Things, book 1, line 110 and book 3, lines 1018-23.

68 Epicurus, "Letter to Herodotus, 62; Lucretius, On the Nature of Things, book 4, lines 794-98.

${ }^{69}$ Deleuze, The Logic of Sense, 277.

${ }^{70}$ For these examples, see Lucretius, On the Nature of Things, book 5, lines 1161-82 and book 4, lines 732-48.

${ }^{71}$ Deleuze, Difference and Repetition, 180.

72 As Hegel defines true and false infinity (wahre and schlechte Unendlichkeit), the latter describes a one-sided progressus in infinitum as the abstract negation of the finite, and the former the manner in which through negation "something comes together with itself," or in other words, a proper Aufhebung: G. W. F. Hegel, The Encyclopaedia Logic: Part I of the Encyclopaedia of Philosophical Sciences, trans. T. F. Geraets et al. (Indianapolis: Hackett, 1991), 149-51. 
73 Deleuze, Difference and Repetition, 178.

${ }^{74}$ Deleuze, Difference and Repetition, 264.

75 Deleuze, Difference and Repetition, 178.

${ }^{76}$ Deleuze, Difference and Repetition, 42-50, 211.

77 Gilles Deleuze and Félix Guattari, What is Philosophy?, trans. H. Tomlinson and G.

Burchell (New York: Columbia University Press, 1994), 37.

${ }^{78}$ Deleuze and Guattari, What is Philosophy?, 36.

79 Deleuze and Guattari, What is Philosophy?, 118.

80 Deleuze and Guattari, What is Philosophy?, 118.

81 Deleuze, Difference and Repetition, 191.

${ }^{82}$ Aristotle, Metaphysics, 1047a35-b1.

83 Deleuze, Difference and Repetition, 211.

${ }^{84}$ Deleuze, Difference and Repetition, 208.

${ }^{85}$ Deleuze, Difference and Repetition, 212

86 Deleuze and Guattari, What is Philosophy?, 22. Deleuze's discussion of virtuality and criticism of possibility are unambiguously borrowed from Bergson. Compare the contrasts among modalities in Bergson's essay "The Possible and the Real”, in The Creative Mind: an Introduction to Metaphysics, trans. M. L. Andison. (New York: Dover, 1946), 73-86, with Deleuze's formulations in Difference and Repetition. See also C. Boundas, “Deleuze-Bergson: An ontology of the virtual." Lest the reader draw false conclusions about the derivation of Deleuze's virtual from Epicurus, the virtual is Bergsonian in origin, and this style of treating modalities is quite absent from Epicurus. My point here is that in What is Philosophy? Deleuze and Guattari are putting virtuality together with themes from Epicurean physics like infinite speed.

87 Deleuze, Difference and Repetition, 12, 19.

88 Deleuze, Difference and Repetition, 32 and 169-70.

${ }^{89}$ Deleuze and Guattari, What is Philosophy?, 8, 16.

90 Deleuze and Guattari, What is Philosophy?, 21.

91 Deleuze and Guattari, What is Philosophy?, 20.

92 Deleuze and Guattari, What is Philosophy?, 21.

93 Deleuze and Guattari, What is Philosophy?, 118.

94 Cooper, “Vitesses de l'image," 50.

95 Deleuze and Guattari, What is Philosophy?, 118.

96 Deleuze, The Logic of Sense, 1-2.

97 For example: Duffy, “The mathematics of Deleuze's differential logic," 142; Robin Durie, "Problems in the relation between maths and philosophy," 182-3; and

Journal of French and Francophone Philosophy | Revue de la philosophie française et de langue française Vol XXI, No 2 (2013) | http://www.jffp.org | DOI 10.5195/jffp.2013.599 
Levi Bryant, Difference and Givenness: Deleuze's Transcendental Empiricism and the Ontology of Immanence. (Evanston, IL: Northwestern University Press, 2008), $59,69$.

98 As Leibniz wrote to Arnaud, "I hold this identical principle, differentiated only by the emphasis, to be an axiom, namely, that what is not truly one being is not truly one being either": G. W. Leibniz, Philosophical Essays, ed. and trans. R. Ariew and D. Garber (Indianapolis: Hackett, 1989), 86.

99 Deleuze and Guattari, What is Philosophy?, 35, 202.

100 Deleuze and Guattari, What is Philosophy?, 11.

101 Deleuze and Guattari, What is Philosophy?, 11, 43.

102 Gilles Deleuze and Félix Guattari, A Thousand Plateaus: Capitalism and Schizophrenia, trans. B. Massumi (Minneapolis: University of Minnesota Press, 1987), 381, 386. For a discussion of the political aspects of speed in A Thousand Plateaus, with reference to Virilio's work, see Patrick Crogan, "Theory of State: Deleuze, Guattari, and Virilio on the State, Technology, and Speed," Angelaki 4.2 (1999): 137-48.

103 Deleuze and Guattari, What is Philosophy?, 127. For a solid introductory discussion of this distinction between states of affairs and events see Jacques Brunschwig, "Stoic Metaphysics," in The Cambridge Companion to the Stoics, ed. B. Inwood (New York: Cambridge University Press, 2003), 233-56. For a more comprehensive and difficult treatment, Victor Caston, "Something and Nothing: The Stoics on Concepts and Universals," Oxford Studies in Ancient Philosophy 17 (1999): 145-213. And on Deleuze's appropriation of the bodies-incorporeals distinction, see Beaulieu, "Deleuze et les stoïciens."

104 Deleuze and Guattari, What is Philosophy?, 117-8.

105 Deleuze and Guattari, What is Philosophy?, 153.

106 Deleuze and Guattari, What is Philosophy?, 158.

107 Deleuze and Guattari, What is Philosophy?, 118.

108 Deleuze and Guattari, What is Philosophy?, 119; Lucretius, On the Nature of Things, book 2, line 162 and book 4, 189-93.

${ }^{109}$ Deleuze, Difference and Repetition, 184.

110 Deleuze, The Logic of Sense, 6, 270. The swerve appears this way, for instance, in Cicero's "On Fate." 